Document downloaded from:

http://hdl.handle.net/10251/122877

This paper must be cited as:

Benajes, J.; García Martínez, A.; Monsalve-Serrano, J.; Villalta-Lara, D. (2018). Benefits of E85 versus gasoline as low reactivity fuel for an automotive diesel engine operating in reactivity controlled compression ignition combustion mode. Energy Conversion and Management. 159:85-95. https://doi.org/10.1016/j.enconman.2018.01.015

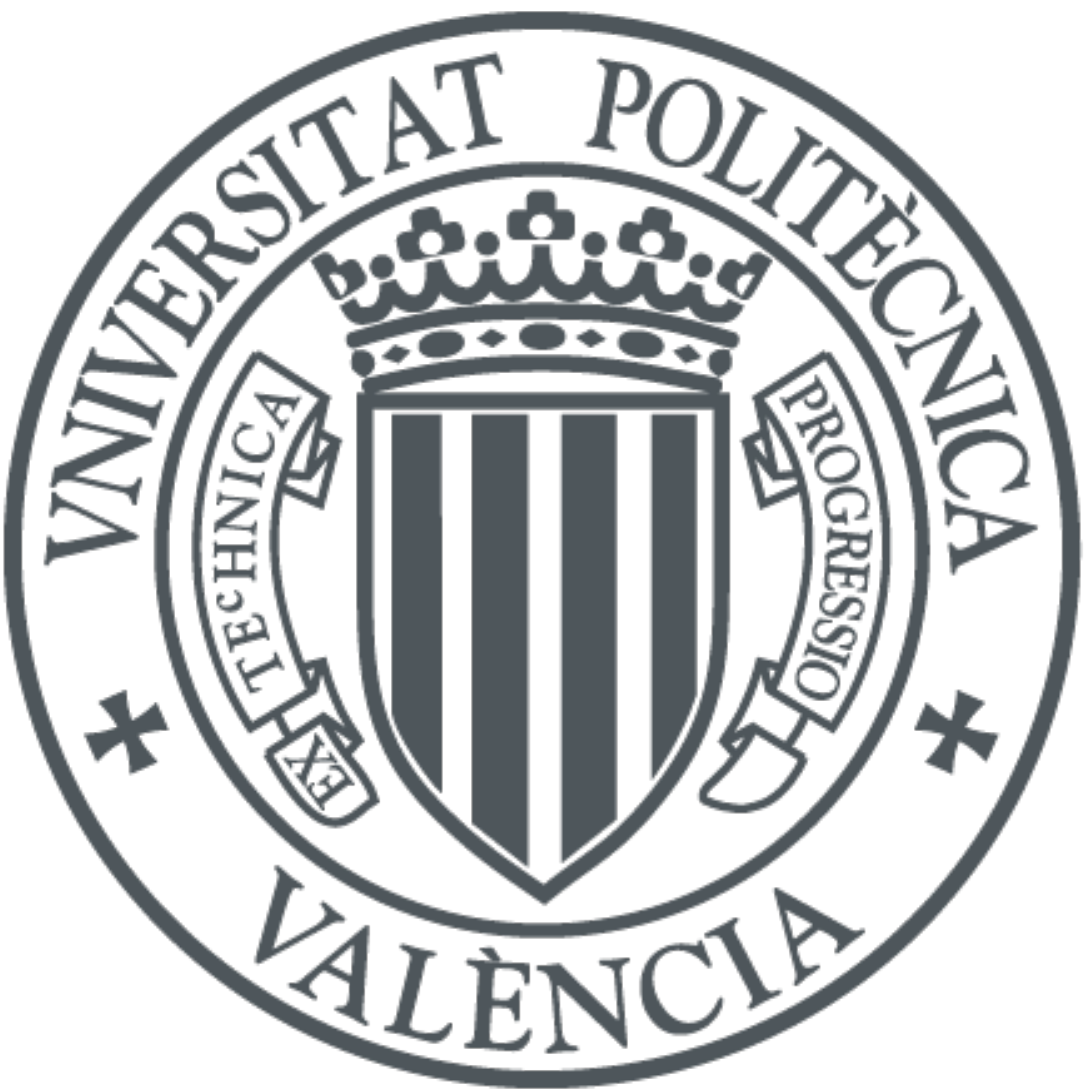

The final publication is available at

https://doi.org/10.1016/j.enconman.2018.01.015

Copyright Elsevier

Additional Information 


\title{
Benefits of E85 versus gasoline as low reactivity fuel for an automotive diesel engine operating in reactivity controlled compression ignition combustion mode
}

Energy Conversion and Management, Volume 159, 1 March 2018, Pages 85-95

https://doi.org/10.1016/j.enconman.2018.01.015

\author{
Jesús Benajes, Antonio García, Javier Monsalve-Serrano* and David Villalta \\ CMT - Motores Térmicos, Universitat Politècnica de València, Camino de Vera s/n, \\ 46022 Valencia, Spain
}

Corresponding author $\left({ }^{*}\right)$ :

Dr. Javier Monsalve-Serrano (jamonse1@mot.upv.es)

Phone: +34 963879659

Fax: +34963877659

\begin{abstract}
This work shows the capabilities of E85 fuel to be used as low reactivity fuel in a high compression ratio light-duty diesel engine (17.1:1) running under reactivity controlled compression ignition concept. To do this, experimental steady-state engine maps are obtained in a single-cylinder engine with diesel-E85 fuel combination. The engine mapping was performed following the same procedure used in previous works with other fuel combinations to allow the results comparison. Considering the mechanical and emissions limits imposed during the engine mapping, it was found that with dieselE85 the combustion concept is limited to the region defined from 2 to 7 bar at $1000 \mathrm{rpm}$, and from 1.5 to 9 bar indicated mean effective pressure at $3000 \mathrm{rpm}$. This operating region was satisfied with nitrogen oxides, soot and pressure rise rate levels below 0.4 $\mathrm{g} / \mathrm{kWh}, 0.01 \mathrm{~g} / \mathrm{kWh}$ and $10 \mathrm{bar} / \mathrm{CAD}$, respectively. The reactivity controlled compression ignition maps with diesel-E85 were obtained taking as reference the total fuel energy used in a previous work to map the engine with diesel-gasoline. The direct comparison of both combustion concepts (diesel-E85 and diesel-gasoline) revealed that E85 allows to extend the engine map around 2 bar indicated mean effective pressure towards the high load region. Moreover, the minimum load achieved at high engine speeds was decreased down to 1.5 indicated mean effective pressure. Finally, the differences in terms of emissions and performance between both reactivity controlled compression ignition concepts are highlighted by doing the difference between the maps of several variables.
\end{abstract}

\section{Keywords}

Reactivity controlled compression ignition; Dual-fuel combustion; Engine map; Efficiency; Ethanol

\section{Introduction}

Excellent combination of engine efficiency and performance has made compression ignition $(\mathrm{Cl})$ engines a widely used technology for transportation worldwide. However, the biggest challenge that $\mathrm{Cl}$ engines are facing is the existing trade-off between nitrogen oxides (NOx) and smoke emissions during the combustion process [1]. Due to 
the evolution of the emissions regulations towards more stringent scenarios, the engine manufacturers are forced to mitigate these pollutants by different means. In this sense, current $\mathrm{Cl}$ engines operated under conventional diesel combustion (CDC) have included aftertreatment equipment in order to reduce the emissions generated during combustion. Aftertreatment systems for $\mathrm{Cl}$ consists of a selective catalyst reduction (SCR) for NOx emissions, diesel particulate filter (DPF) for the soot content at the exhaust gases, and diesel oxidation catalyst (DOC) to reduce hydrocarbons (HC) and carbon monoxide (CO) emissions.

Aftertreatment systems allow the harmful emissions be reduced below the limitations imposed by the emissions regulations [2]. However, these elements provide an increase of the engine complexity and imply an extra cost at the production budget [3]. In addition, these systems usually make use of exhaust fluids such as urea to enhance the SCR reduction capacity and diesel fuel for the DPF regeneration. Although it has been dedicated a huge effort to minimize the operational costs of the aftertreatment sytems [4], they also provoke an inherent fuel consumption penalty due to the back pressure increase caused in the exhaust line [5].

To reduce the aftertreatment necessities, alternative combustion processes should be implemented to minimize the emissions levels generated during the combustion process [6]. In this sense, the low temperature combustion strategies (LTC) have been proved to be able to achieve high engine efficiency while reducing simultaneously NOx and smoke emissions [7][8]. These strategies use highly diluted fuel-air mixtures [9] increasing the mixing time prior to the start of the combustion [10], which provide a simultaneous reduction in both harmful pollutants. Moreover, the efficiency is improved due to fast combustion processes and reduced heat transfer [11].

Homogeneous charge compression ignition $(\mathrm{HCCl})$, partially premixed combustion (PPC), reactivity controlled compression ignition (RCCl) or dual-fuel combustion [12][13] are the most studied LTC concepts by the research community. Diesel $\mathrm{HCCl}$ has been widely investigated during the recent years [14]. The high fuel-air premixing levels used with $\mathrm{HCCl}$ allow reducing the NOx and soot formation to virtually zero [15]. In addition, due to the fast heat release, high thermal efficiency can be achieved in the operating range in which the combustion process can be controlled. However, since chemical kinetics dominate the combustion onset, the operating range is too small, being limited by the appearance of high pressure gradients and combustion noise. In particular, the operating range of the $\mathrm{HCCl}$ strategy is limited to partial engine load [16]. Additionally to these problems, $\mathrm{HCCl}$ presents another challenges such as cold start and excessive $\mathrm{CO}$ and unburned HC [17] levels, which limited its potential to be used in real engines.

Gasoline PPC has been deeply studied as a possible solution for the shortcomings found with $\mathrm{HCCl}$ [18][19]. PPC strategy allows setting more delayed injection timings thanks to using a fuel with lower reactivity than diesel. This enables better control of the combustion phasing as load increases, which makes possible the reduction of the knocking phenomenon [20]. As the combustion phasing results in a better control due to the use of gasoline-like fuels, the control of the heat release was also improved and allowed this concept to reduce the NOx emissions compared to conventional combustion strategies [21][22]. Additional studies under PPC mode were carried out in order to improve the understanding of using gasolines with different research octane 
number (RON), resulting that gasolines with $\mathrm{ON}$ higher than 91 produce excessive unburned HC. Installing a spark plug would solve the cycle-to-cycle dispersion that was causing such a high levels of unburned HC [23], but the benefits observed at the NOx and smoke emissions were missed [24].

Inagaki et al. [25] operated a dual-fuel premixed compression ignition (PCl) combustion strategy using two fuels of different reactivity. The in-cylinder reactivity was controlled by modifying the fuels percentages using two injector systems. This provided an excellent control of the combustion onset and extremely low NOx and soot emissions simultaneously. These conclusions were later confirmed by Kokjohn et al. [26], which named this dual-fuel LTC technique as reactivity controlled compression ignition (RCCI).

$\mathrm{RCCl}$ has been found to be the most promising LTC concept in terms of efficiency, emissions and engine load range of operation [27]. Major part of these benefits come from the use of two fuels with different reactivity. The possibility of adjusting the reactivity on demand provides an upgraded control of the combustion [28] and thereby, can overcome the main limitations of the LTC concepts, mainly the combustion stability. Nonetheless, RCCl has still several challenges to face, such as unburned HC and CO emissions during the low engine load operation [29]. Maximum pressure rise rates (MPRR) and in-cylinder peak pressure are reduced with $\mathrm{RCCl}$ due to the more sequential autoignition obtained thanks to the high reactivity fuel (HRF) stratification [30]. However, these two factors still limit the $\mathrm{RCCl}$ operating range to moderate loads, compromising its application under real engine conditions [31].

Several studies have been carried out in order to extend the application range of RCCI. The dual-mode concept implies to operate with other combustion mode when it is critical for $\mathrm{RCCl}$ [32]. Thus, dual-mode RCCI/CDC could become a great potential option when high compression ratios $(\approx 17: 1)$ are used, as demonstrated in both medium-duty [33] and light-duty engines [31]. Another route to solve the shortcomings of the RCCI mode is using a lower compression ratio $(\approx 15: 1)$ to implement a concept known as dualmode dual-fuel (DMDF) [34]. This DMDF concept allows to operate the engine from low load to full load in dual-fuel conditions, using RCCl in the lower portion of the map and diffusive dual-fuel combustion from the $75 \%$ engine load to full load. In addition, DMDF shows an excellent potential due to its low NOx emissions (below $0.4 \mathrm{~g} / \mathrm{kWh}$ up to $75 \%$ engine load) and ultra-low smoke emissions [35]. In both dual-mode concepts, the major benefits in terms of NOx and soot emissions reduction are obtained in the RCCI portion of the map [36]. Thus, it is crucial to extend pure $\mathrm{RCCl}$ operating range in order to improve the global engine map emissions.

As literature demonstrates, the $\mathrm{RCCl}$ concept can be implemented using a wide variety of fuels apart from diesel and gasoline [37]. The most widely used high reactivity fuel is diesel [38]. Some other fuels such as gasoline doped with a cetane improver [39] or diesel-gasoline mixtures have been tested without relevant improvements [40]. By contrast, it has been proved that the low reactivity fuel physical and chemical characteristics have greater effects on RCCl emissions and performance [41]. In this sense, it was found that using fuels with lower reactivity than gasoline such as ethanol [42][43], methanol [44] and other biofuels [45] can contribute to reduce the MPRR and $P_{\max }$ at higher loads. Considering this background, the objective of this work is to assess the capabilities of using ethanol (E85) as a low reactivity fuel to extend the $\mathrm{RCCl}$ 
operating range in a high compression ratio engine ( $\approx 17.5: 1)$. To do this, experimental steady-state engine maps are obtained in a single-cylinder engine with diesel-E85 fuel combination. Later, the mapping results are compared to those obtained in a previous work using diesel-gasoline as pair of fuels [46] in the same engine platform.

\section{Materials and methods}

\subsection{Engine and test cell description}

The single-cylinder diesel engine (SCE) used for the experiments is based on a serial production light-duty $1.9 \mathrm{~L}$ platform. The engine has four valves driven by dual overhead cams. The piston used is the serial one, with a re-entrant bowl that confers a geometric compression ratio of 17.1:1. The swirl ratio was fixed at 1.4 using the tangential and helical valves located in the intake port [47], which is a representative value of that used in the stock engine configuration. The Table 1 summarizes the more relevant characteristics of the engine.

Table 1. Engine characteristics.

\begin{tabular}{|c|c|}
\hline Engine Type & 4 stroke, 4 valves, direct injection \\
\hline Number of cylinders [-] & 1 \\
\hline Displaced volume $\left[\mathrm{cm}^{3}\right]$ & 477 \\
\hline Stroke $[\mathrm{mm}]$ & 90.4 \\
\hline Bore $[\mathrm{mm}]$ & 82 \\
\hline Piston bowl geometry [-] & Re-entrant \\
\hline Compression ratio [-] & 17.1:1 \\
\hline Rated power [kW] & $27.5 @ 4000$ rpm \\
\hline Rated torque [Nm] & $80 @ 2000-2750$ rpm \\
\hline
\end{tabular}

The scheme of test cell in which the engine is operated is shown in Figure 1. An electric dynamometer is used for the engine speed and load control during the experiments. The air intake line is composed of a screw compressor that feeds the engine with fresh air at a pressure up to 3 bar, heat exchanger and air dryer to modify the temperature and relative humidity of the air, airflow meter and a settling chamber sized to attenuate the pulsating flow. Moreover, pressure and temperature transducers are instrumented in this element with regulation purposes. The exhaust gas recirculation (EGR) is introduced in the intake line, downwards the settling chamber, through a dedicated line composed of a heat exchanger, settling chamber and regulation valve. EGR temperature is monitored in several points along the line for its control. Finally, the pressure and temperature of the air-EGR mixture is measured in the intake manifold before entering to the cylinder.

As sketched in the figure, the in-cylinder pressure signal was acquired for the combustion analysis using a Kistler $6125 \mathrm{C}$ glow-plug piezoelectric transducer in series with a 4603B10 charge amplifier. Data from 400 consecutive engine cycle were acquired every 0.5 crank angle degree (CAD). The data was recorded using a Yokogawa DL708E with a 16 bits $A / D$ converter module. The low frequency variables were acquired at a frequency of $100 \mathrm{~Hz}$ using an in-house developed recording system named SAMARUC.

The first elements of the exhaust line are the pressure and temperature transducers located in the exhaust manifold. After them, a settling chamber was installed to 
attenuate the exhaust flow before the EGR bypass. Later a pneumatic valve was used to reproduce the backpressure provoked by the turbocharger in the real multi-cylinder engine. The last elements of the exhaust line are the emissions analyzers. A five-gas Horiba MEXA-7100 DEGR analyzer is used to measure the gaseous engine-out emissions. Each steady-state operating points was measured three times along a period of 60 seconds. Finally, an AVL 415S smoke meter was used to measure the smoke emissions in filter smoke number (FSN) units. Three consecutive measurements of 1 liter volume each with paper-saving mode off were took at each engine operating point. The accuracy of the main elements of the test cell is shown in Table 2.

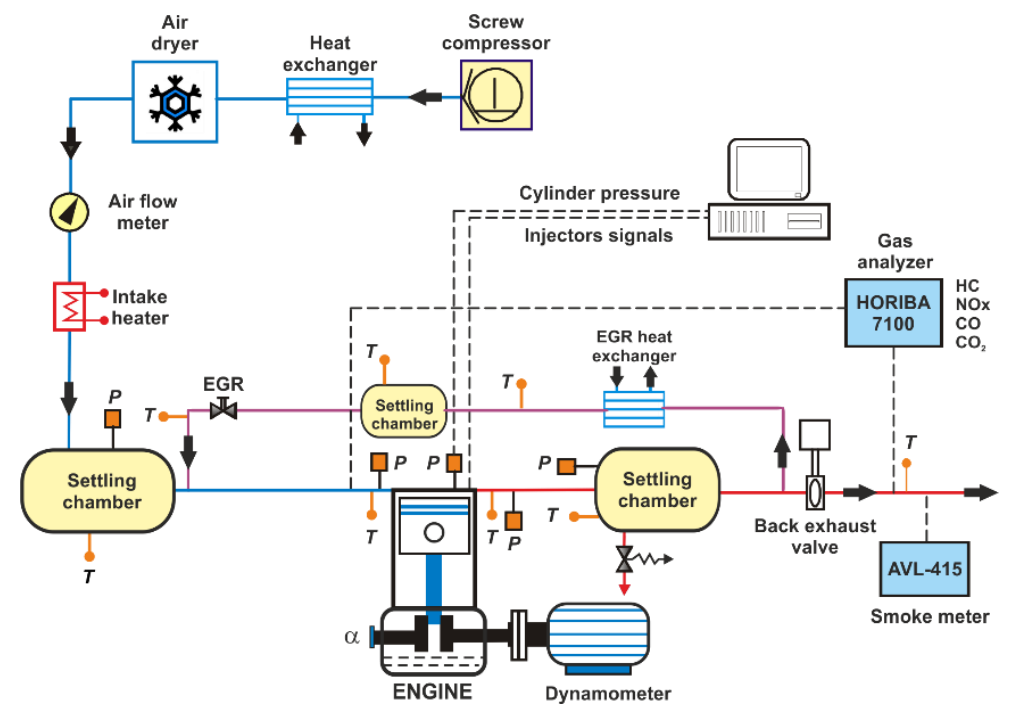

Figure 1. Test cell scheme.

Table 2. Accuracy of the instrumentation used in this work.

\begin{tabular}{|l|l|l|l|}
\hline Variable measured & Device & Manufacturer / model & Accuracy \\
\hline In-cylinder pressure & Piezoelectric transducer & Kistler / 6125BC & \pm 1.25 bar \\
\hline Intake/exhaust pressure & Piezorresistive transducers & Kistler / 4603B10 & \pm 25 mbar \\
\hline $\begin{array}{l}\text { Temperature in settling } \\
\text { chambers and manifolds }\end{array}$ & Thermocouple & TC direct / type K & $\pm 2.5{ }^{\circ} \mathrm{C}$ \\
\hline Crank angle, engine speed & Encoder & AVL / 364 & $\pm 0.02 \mathrm{CAD}$ \\
\hline $\mathrm{NOx}, \mathrm{CO}, \mathrm{HC}, \mathrm{O}_{2}, \mathrm{CO}_{2}$ & Gas analyzer & $\begin{array}{l}\mathrm{HORIBA} / \mathrm{MEXA} 7100 \\
\text { DEGR }\end{array}$ & $4 \%$ \\
\hline FSN & Smoke meter & AVL / 415 & $\pm 0.025 \mathrm{FSN}$ \\
\hline Gasoline/diesel fuel mass flow & Fuel balances & AVL / 733S & $\pm 0.2 \%$ \\
\hline Air mass flow & Air flow meter & Elster / RVG G100 & $\pm 0.1 \%$ \\
\hline
\end{tabular}

\subsection{Fuels and injection systems characteristics}

The complete layout of the injection system with all the auxiliary elements for RCCI operation is shown in Figure 2. As sketched, the EN590 diesel fuel was injected into the cylinder by means of a centrally located solenoid direct injector (DI) coupled with a common-rail fuel injection system. The injection settings were managed using a DRIVVEN controller. The E85 fuel was fumigated in the intake manifold using a port fuel injection (PFI) located $160 \mathrm{~mm}$ far from the intake valves, which was governed through a Genotec unit. The mass flow rate of both fuels was measured using dedicated AVL 
733S fuel balances. The main characteristics of the DI and PFI are depicted in Table 3, and the most relevant properties of the diesel and E85 fuel used in this study are summarized in Table 4. Moreover, the properties of the gasoline used in the previous work that will be used for comparison, are depicted in Table 4 [46]. All the properties were measured following the American society for testing and materials (ASTM) standards.

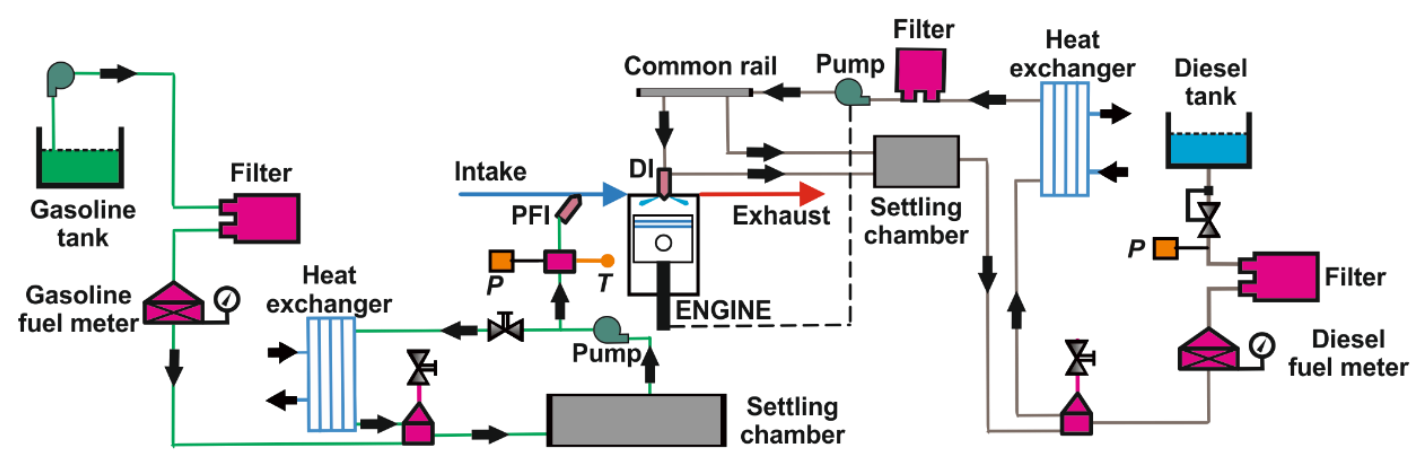

Figure 2. Fuel injection systems scheme.

Table 3. Characteristics of the direct and port fuel injector.

\begin{tabular}{|c|c|c|c|}
\hline \multicolumn{2}{|l|}{ Direct injector } & \multicolumn{2}{|l|}{ Port fuel injector } \\
\hline Actuation Type [-] & Solenoid & Injector Style [-] & Saturated \\
\hline Steady flow rate @ 100 bar $\left[\mathrm{cm}^{3} / \mathrm{min}\right]$ & 880 & Steady flow rate @ 3 bar $\left[\mathrm{cm}^{3} / \mathrm{min}\right]$ & 980 \\
\hline Included spray angle $\left[{ }^{\circ}\right]$ & 148 & Included Spray Angle [ $\left.{ }^{\circ}\right]$ & 30 \\
\hline Number of holes [-] & 7 & Injection Strategy [-] & single \\
\hline Hole diameter $[\mu \mathrm{m}]$ & 141 & Start of Injection [CAD ATDC] & 340 \\
\hline Maximum injection pressure [bar] & 1600 & Maximum injection pressure [bar] & 5.5 \\
\hline
\end{tabular}

Table 4. Physical and chemical properties of the fuels.

\begin{tabular}{|l|c|c|c|}
\cline { 2 - 4 } \multicolumn{1}{c|}{} & Diesel EN590 & E85 & Gasoline \\
\hline Density $\left[\mathrm{kg} / \mathrm{m}^{3}\right]\left(\mathrm{T}=15^{\circ} \mathrm{C}\right)$ & 842 & 781 & 0.747 \\
\hline Viscosity $\left[\mathrm{mm}^{2} / \mathrm{s}\right]\left(\mathrm{T}=40^{\circ} \mathrm{C}\right)$ & 2.929 & - & 0.545 \\
\hline RON $[-]$ & - & 108 & 97.6 \\
\hline MON [-] & - & 89 & 89.7 \\
\hline Ethanol content $[\%$ vol.] & - & 84.7 & $<5$ \\
\hline Cetane number $[-]$ & 51 & - & - \\
\hline Lower heating value $[\mathrm{MJ} / \mathrm{kg}]$ & 42.50 & 31.56 & 44.09 \\
\hline
\end{tabular}

\subsection{In-cylinder pressure signal processing}

The combustion analysis was performed through the in-cylinder pressure signal analysis using an in-house developed single-zone model (CALMEC). For processing the data, the model needs to be fed with instantaneous and mean variables from the experiments such as temperatures and pressures of the coolant, oil, air, EGR and intake charge, among others.

The raw pressure signals from 400 consecutive combustion cycles at each engine operating condition are provided to the model. Later, a representative pressure trace is 
obtained by averaging all the pressure traces, which are previously smoothed using a Fourier series low-pass filter. Then, the representative pressure trace is used for the analysis. To do so, the first law of thermodynamics for open systems is applied to the period defined between the intake valve closing (IVC) and exhaust valve opening (EVO). The mean gas temperature in the chamber is calculated using the ideal gas equation of state, while the rest of the gas thermodynamic properties are obtained using the pressure signal. These properties are used as input for the heat transfer sub-models implemented in CALMEC [48]. Using the data from the convective and radiative heat transfer, the wall temperatures are calculated by means of a lumped conductance model. The fluid-dynamic conditions in the ports and the heat transfer flows in these elements are calculated with a dedicated filling-emptying sub-model embedded in CALMEC.

The main results from CALMEC used in this work are the rate of heat release (RoHR), bulk gas temperature, maximum in-cylinder pressure $\left(P_{\max }\right)$ and pressure rise rate (PRR). Moreover, some parameters for describing the combustion process such as the start of combustion (SOC) and combustion phasing (CA50) are used. In this study, the SOC is defined as the crank angle in which the $5 \%$ of the heat release is cumulated, while the CA50 represents the angle of $50 \%$ heat released. A box chart summarizing the flux of information for the in-cylinder pressure signal analysis is shown in Figure 3.

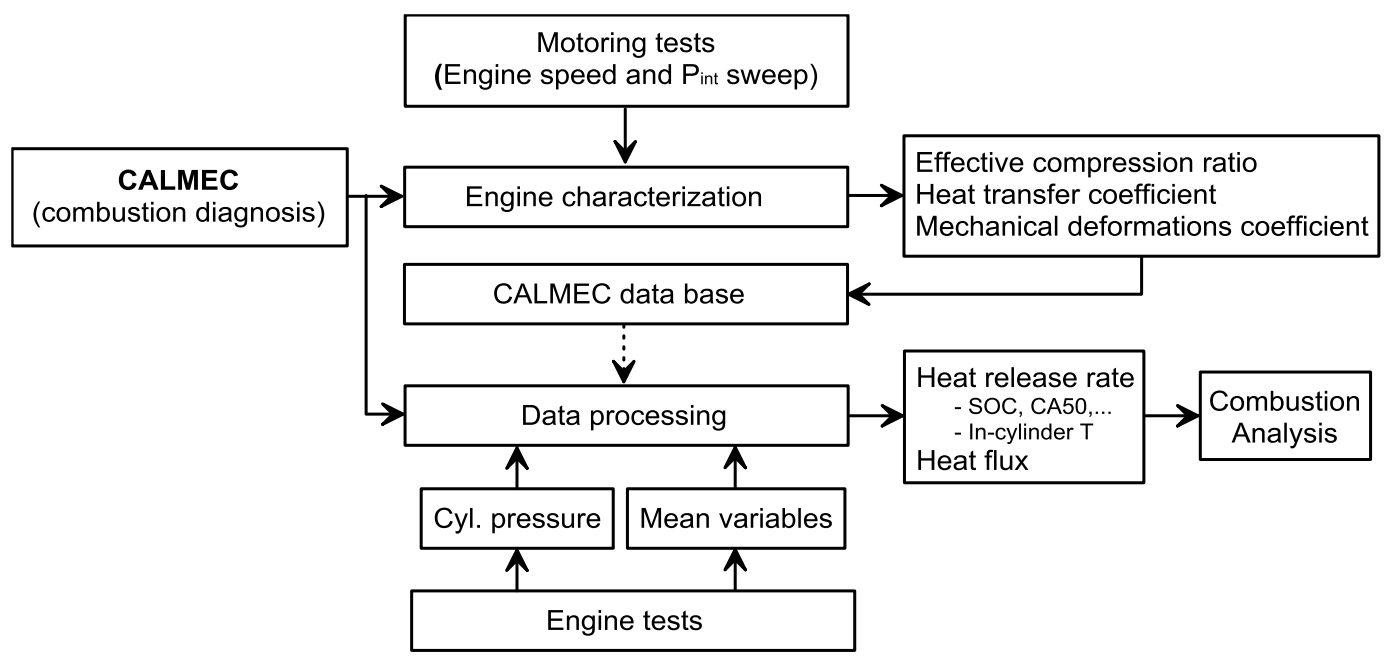

Figure 3. Summary of the information flux for the in-cylinder pressure signal analysis.

\subsection{Engine mapping methodology}

The methodology followed for mapping the engine is described in detail in previous works [27][33]. Several variables were restricted during the engine mapping procedure. A primary objective was to achieve ultra-low NOx and soot emissions (ISNOx $<0.4$ $\mathrm{g} / \mathrm{kWh}$, Smoke $<0.4 \mathrm{FSN})$. To ensure a reasonable combustion efficiency, unburned products were limited trough the $\mathrm{CO}$ emissions (ISCO $<5000 \mathrm{ppm}$ ). Finally, the mechanical limits of the engine were preserved by constraining the maximum incylinder pressure gradients and peak pressure (PPR $<10$ bar/CAD and $P_{\max }<160$ bar).

Methodologically, the final points of the engine map were reached by means of three consecutive steps, which are summarized in Figure 4. As the figure shows, the aim of the first step was to achieve stable $\mathrm{RCCl}$ operation (coefficient of variation, COV $<4 \%$ ) through the gasoline fraction (GF) and diesel start of injection (SOI) modification, 
without taking care about the limitations imposed. In the next step, the EGR is also tuned to reduce the NOx and soot emissions levels down to the values imposed considering not to exceed the mechanical limits. At the same time, GF and diesel SOI are readjusted to improve the performance-emissions trade-off at this point. The last step consists of refining slightly the calibration in terms of EGR and diesel SOI to try to reduce the unburned products and the fuel consumption without exceeding the rest of the limitations.

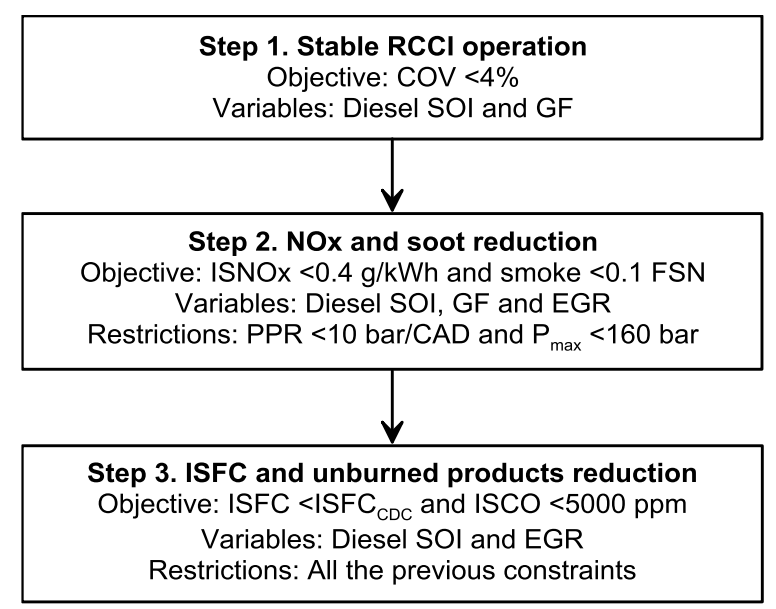

Figure 4. Summary of the experimental procedure followed for mapping the engine.

The parameter defined in previous works for accounting the gasoline-to-total fuel ratio in each operating point was the GF, defined as the mass ratio of gasoline-to-total fuel. Since the lower heating value (LHV) of diesel and gasoline are reasonably similar, the GF is also representative of the port-to-direct energy ratio delivered to the cylinder. However, due to the very low LHV of E85 as compared to diesel, the premixed energy ratio (PER) is defined here. As shown in Equation 1, the PER accounts the energy ratio of the low reactivity fuel to the total energy:

$$
\operatorname{PER}[\%]=\frac{\mathrm{m}_{\mathrm{LRF}} \cdot \mathrm{LHV}_{\mathrm{LRF}}}{\mathrm{m}_{\mathrm{HRF}} \cdot \mathrm{LHV}_{\mathrm{HRF}}+\mathrm{m}_{\mathrm{LRF}} \cdot \mathrm{LHV}_{\mathrm{LRF}}}
$$

where the LRF, HRF and LHV stand for low reactivity fuel, high reactivity fuel and lower heating value, respectively.

Finally, it is interesting to remark that during the engine mapping, the total energy delivered to the cylinder per stroke was tried to kept constant to the same values found with diesel-gasoline [46]. As will be shown in section 3.2, some discrepancies were inevitable due to differences between diesel-gasoline (D-G) and diesel-ethanol (D-E85) combustion characteristics, which led to differences in gross indicated efficiency.

\section{Results and discussion}

\subsection{Diesel-E85 RCCI mapping}

This section presents the $\mathrm{RCCl}$ engine mapping results using E85 as low reactivity fuel. Moreover, the frontiers of minimum and maximum load achieved in a previous work with diesel-gasoline fuel combination are marked in the maps [46]. As it can be seen, the use of E85 allowed to extend the engine map around 2 bar indicated mean effective pressure (IMEP) towards the high load region for all engine speeds. The minimum load achieved at the low speed region remained unchanged versus using gasoline, while at 
higher engine speeds the low load frontier was reduced down to 1.5 bar IMEP. The maps results for both $\mathrm{RCCl}$ concepts (diesel-E85 and diesel-gasoline) will be directly compared in the next section.

The Figure 5 shows the results for NOx and smoke emissions. The NOx emissions map was covered with values below $0.4 \mathrm{~g} / \mathrm{kWh}$, being the greatest levels found in the low load region for all engine speeds. This is consequence of using low PER and EGR (Figure 6) to minimize hydrocarbons $(\mathrm{HC})$ and carbon monoxide (CO) levels. The high NOx emissions at high load and middle engine speeds are expected to be consequence of a high temperature combustion with richer equivalence ratios (Figure 7). Under these conditions, NOx levels are higher when PRR and $P_{\max }$ are higher (Figure 8), which denote more constant volume-like and spiky combustion processes. Smoke levels are virtuallyzero in almost the whole engine map. Only three peninsulas of high emission rate are found, which should be consequence of particular engine settings combinations (e.g., delayed diesel $\mathrm{SOI}$ and high equivalence ratio). At these peninsulas, the smoke levels do not exceed 0.4 FSN, which is far below the typical values achieved with CDC.
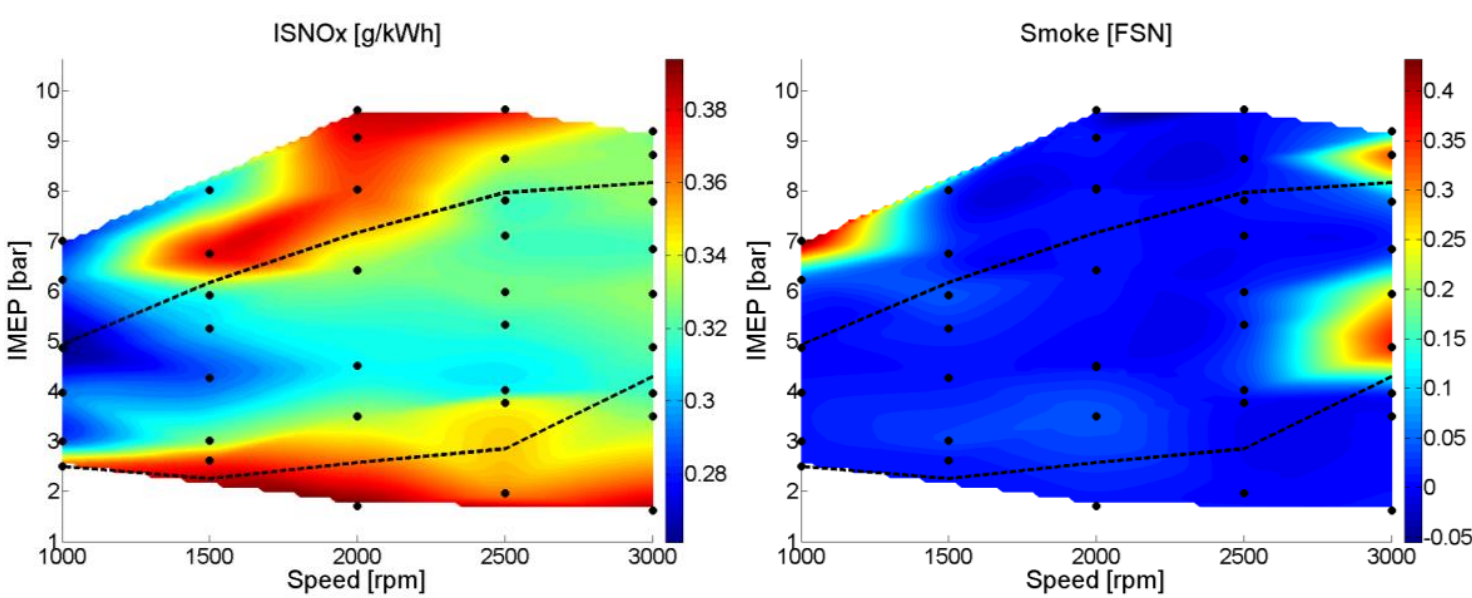

Figure 5. NOx and smoke emissions maps with diesel-E85.

As shown in Figure 6, the PER trend is mainly governed by the engine load. From 1-4 bar IMEP, the PER is lower to minimize the unburned products and increase the combustion stability. In any case, this region is covered with PER values ranging around $50-60 \%$ to contain the NOx emissions levels. The PER increases as load increases, reaching values of $75-85 \%$ in the high load region at middle engine speeds. At high engine speeds, the maximum PER is reduced to increase the fuel reactivity for compensating the shorter time available for the combustion event. The EGR trend is similar to that of PER. In this sense, the lower EGR levels are found in the low load portion of the map to improve the combustion process. Later, the EGR increases with the engine load, being the major part of the map covered with levels near $40 \%$. Maximum EGR peaks of around $42 \%$ were necessary in some high load points to maintain the NOx levels below $0.4 \mathrm{~g} / \mathrm{kWh}$. 

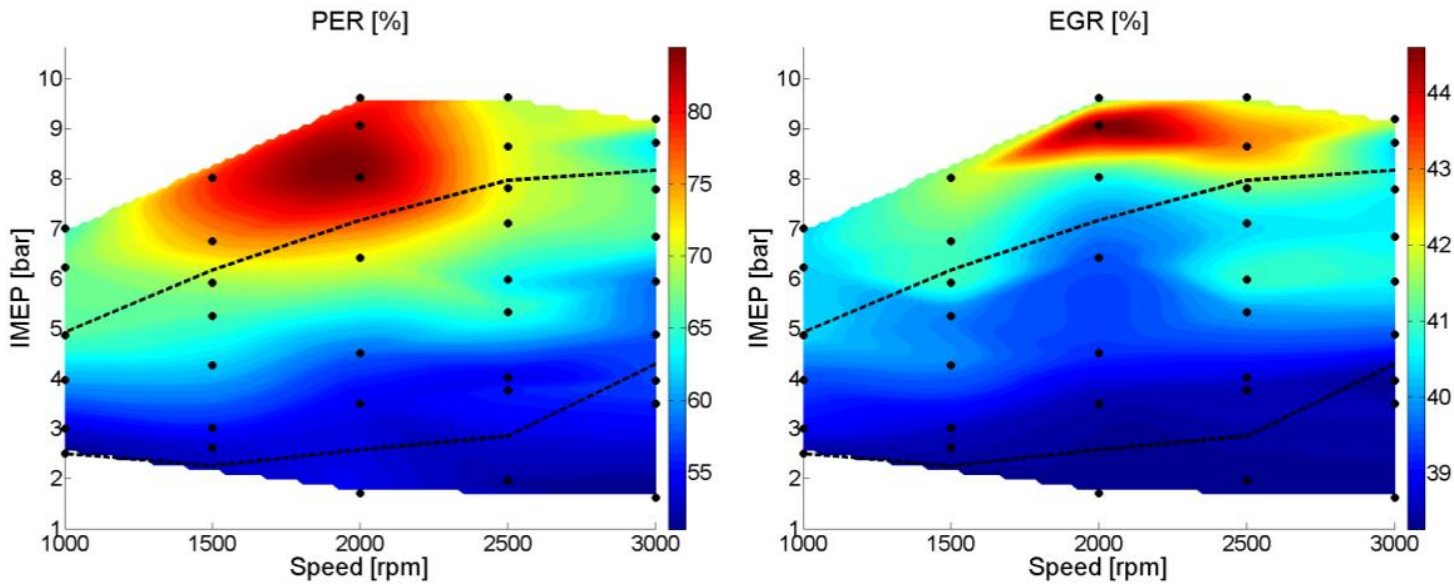

Figure 6. PER and EGR rate maps with diesel-E85.
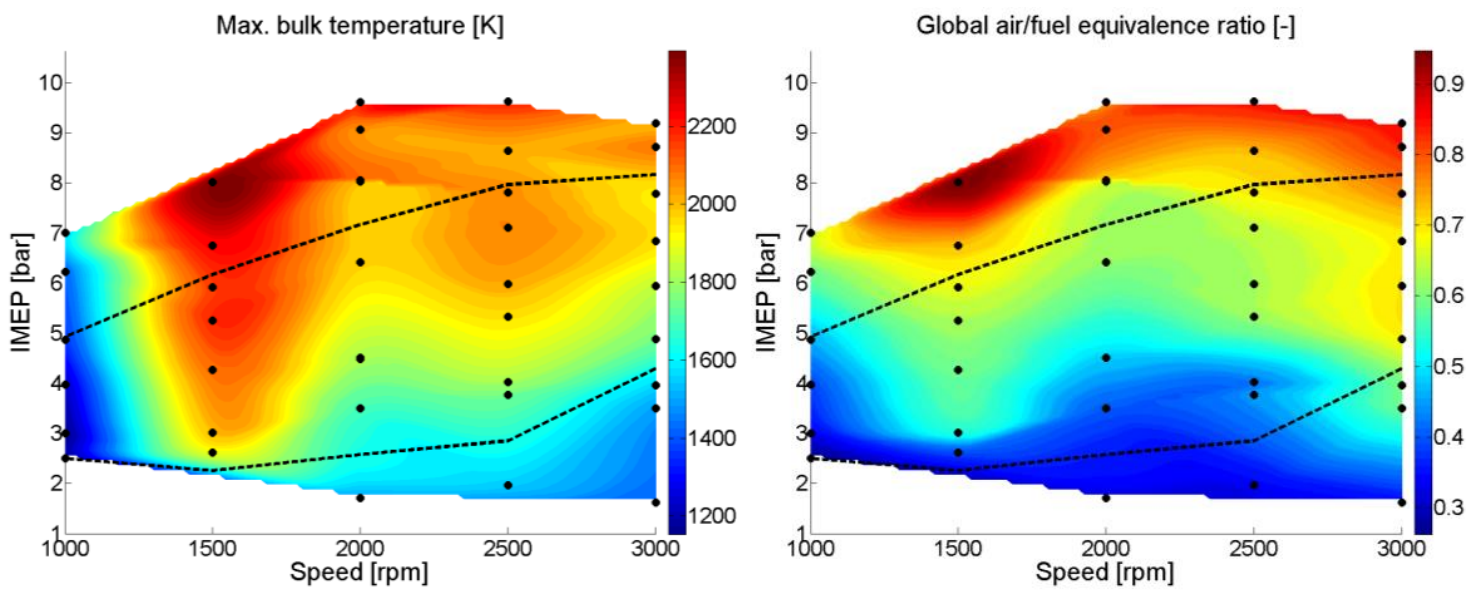

Figure 7. Maximum bulk gas temperature and global equivalence ratio maps with diesel-E85.
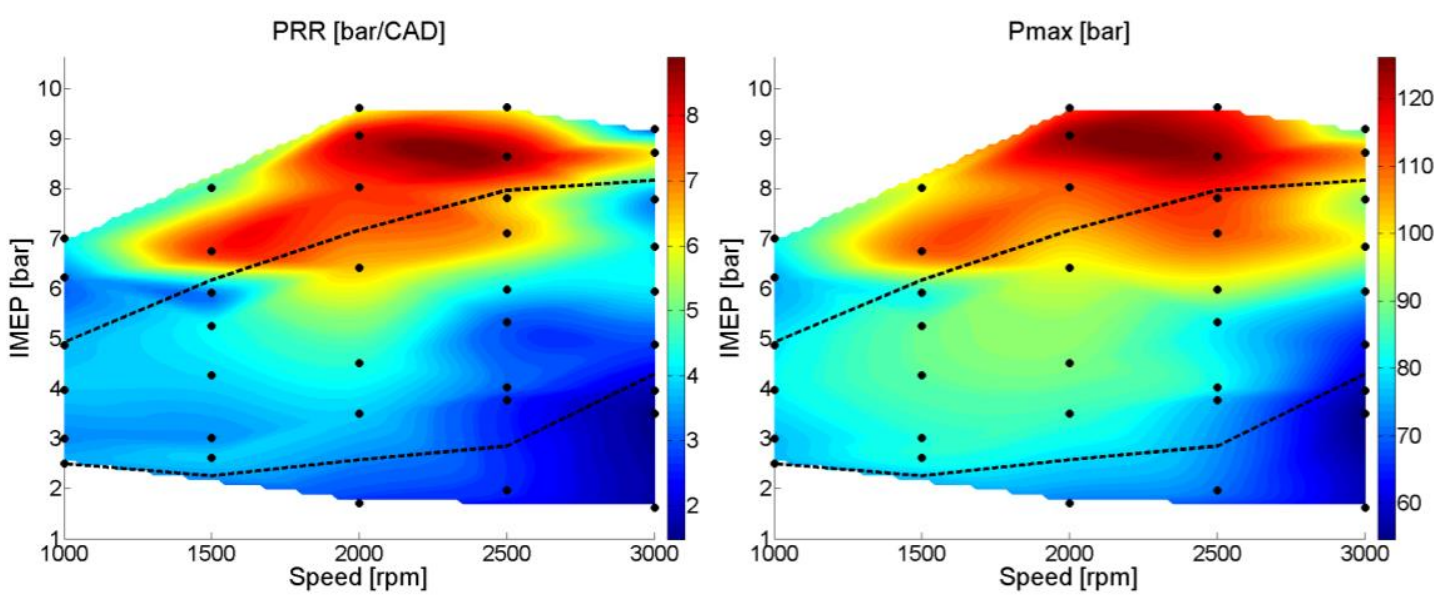

Figure 8. PRR and $P_{\max }$ maps with diesel-E85.

As Figure 9 shows, $\mathrm{HC}$ and $\mathrm{CO}$ emissions trends are equal. In both cases, the highest emission rate is located in the low-load high-speed region of the map. This occurs due to the low reactivity of E85 fuel. The poor combustion leads to low bulk gas temperatures (Figure 7), which inhibits the complete oxidation of the fuel. This fact is aggravated by the low global equivalence ratio used, which had to be restricted to not exceed the NOx limit (Figure 5). Even using the lowest PER and EGR levels (Figure 6), the $\mathrm{HC}$ and $\mathrm{CO}$ emissions rates reach 45 and $90 \mathrm{~g} / \mathrm{kWh}$, respectively. Above 3.5 bar IMEP, 
the emissions levels of both pollutants are substantially reduced, with their levels being in the range of $10-20 \mathrm{~g} / \mathrm{kWh}$. Finally, the high load region presents the lowest emissions levels ( $<10 \mathrm{~g} / \mathrm{kWh}$ ), which can be expected looking at the PRR and $\mathrm{P}_{\max }$ maps. High PRR and $P_{\max }$ levels suggest spiky combustion processes with high temperature, and therefore low unburned products and high NOx levels.
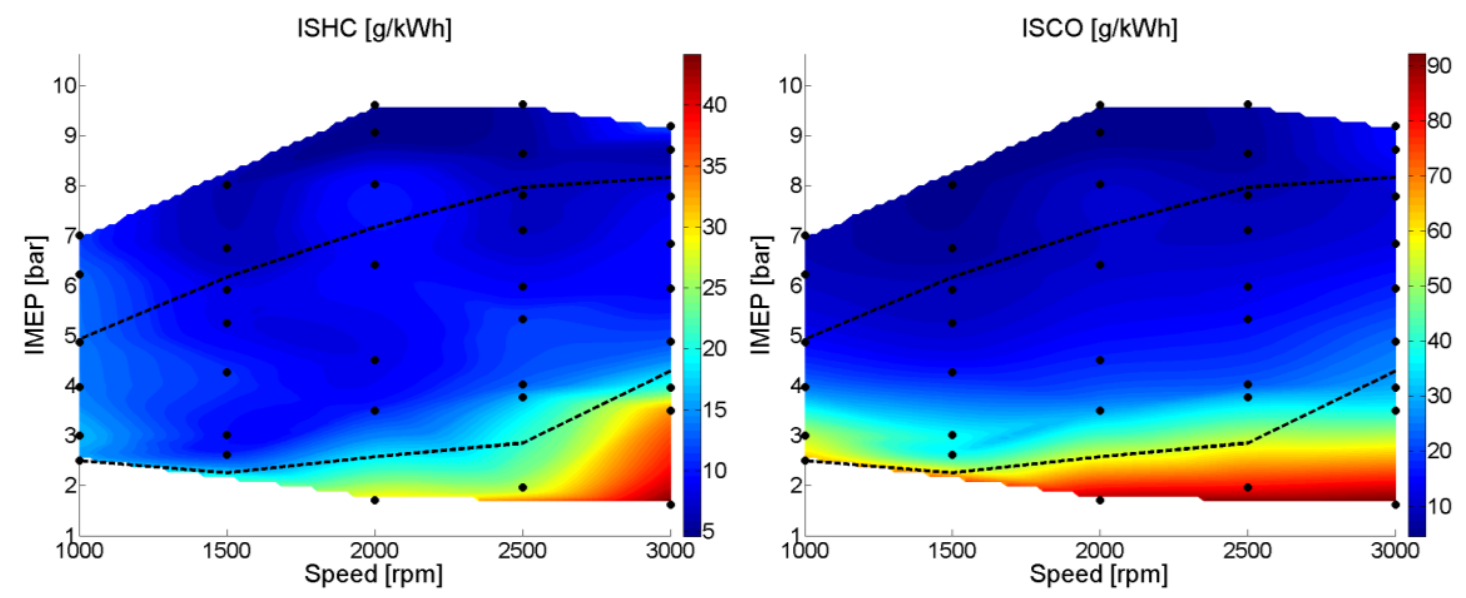

Figure 9. HC and CO emissions maps with diesel-E85.

Figure 10 shows that the diesel SOI and CA50 maps shape are quite similar. This suggests that the diesel fuel injection has a good degree of control over the combustion process. This is a clear advantage in using E85 as low reactivity fuel instead of gasoline. In this sense, the higher enthalpy of vaporization and octane number of E85 allow to compensate the high temperature and pressure achieved during the compression stroke due to the high compression ratio of the engine. In a previous work using diesel-gasoline [46], it was shown that the lack of combustion control resulted in excessively early CA50, which notably reduces the thermodynamic efficiency of the combustion cycle. Regarding the diesel SOI trend, at low load the SOI is more advanced to increase the premixing degree and avoid local rich conditions with the aim of containing the NOx levels in environments with low PER and EGR (Figure 6). Increasing the load, the diesel SOI was a little bit delayed to improve the combustion control degree, with the major part of the map covered with values ranging from -38 to -34 CAD ATDC. Finally, the high load portion of the map was completed with the most delayed SOI values to delay the CA50 and limit the maximum PRR and $\mathrm{P}_{\max }$ (Figure 8).
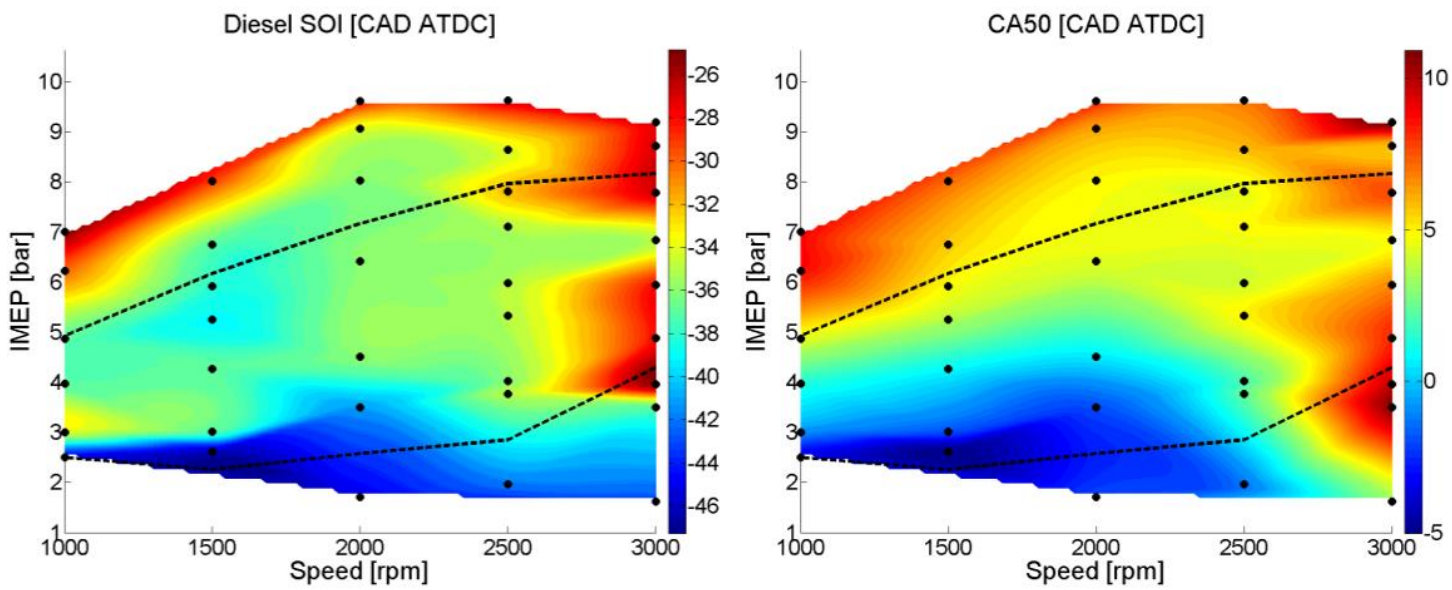

Figure 10. Diesel SOI and CA50 maps with diesel-E85. 


\subsection{Diesel-E85 vs diesel-gasoline operation}

This section compares the diesel-E85 mapping results shown in subsection 3.1 versus the diesel-gasoline maps obtained in a previous work [46] with the aim of highlighting the main differences between both concepts. To do this, a subtraction operation in the region in which both maps overlap (marked in previous figures) has been done. As a result, maps of differences for several variables are presented from Figure 11 to Figure 13.

Figure 11 shows the gross indicated efficiency (GIE) differences between diesel-gasoline and diesel-E85. Considering the GIE definition, this map is equivalent to that of total fuel energy difference between both concepts. As Figure 11 shows, GIE with diesel-gasoline is higher than diesel-E85 for high engine speeds, with the exception of one point at 2500 rpm. Considering the $\mathrm{HC}$ and $\mathrm{CO}$ levels at this point (Figure 12), this drop in GIE for dieselgasoline is expected to be related to low combustion efficiency. At low engine speed, the GIE trend is the inverse, being higher for diesel-E85 in the majority of the operating points. The fuel economy gain with diesel-E85 is explained by a better combustion control. In this sense, the CA50 of the combustion process with diesel-gasoline occurred before TDC in the major part of the map, which reduces the fuel-to-work conversion efficiency. This occurs due to the high in-cylinder pressures and temperatures because of the high compression ratio. The use of E85 as low reactivity fuel improves this situation due to its higher enthalpy of vaporization (which reduces the intake charge temperature) and octane number [49]. Thus, because of the better combustion phasing (CA50), less fuel energy is needed to reach the same engine load. By contrast, at high engine speeds, where the effective time for the combustion process reduces, the low reactivity of E85 causes the CA50 to delay to more than +8 CAD ATDC, penalizing the GIE.

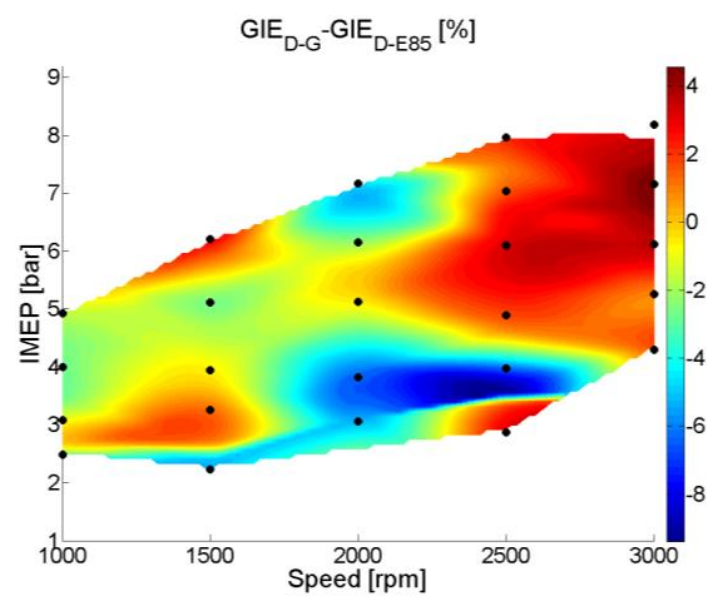

Figure 11. Gross indicated efficiency difference between diesel-gasoline and diesel-E85 maps.

Figure 12 reveals that $\mathrm{HC}$ emissions are higher for D-E85. Previous works have shown that $\mathrm{HC}$ emissions levels are well related to the quantity of low reactivity fuel injected in the cylinder [50]. In this sense, it was found that the amount of low reactivity fuel that reaches the crevice regions is not burned because the impossibility of the high temperature gas to arrive to this cold zone, mainly when using re-entrant piston bowl geometries [51]. In addition, some quantity of LRF is not burned near the centerline of the cylinder [52]. The results shown in Figure 12 follow this reasoning. As it is seen, the 
differences map for $\mathrm{HC}$ and PER have a similar general trend, leading to higher $\mathrm{HC}$ emissions in the map regions where PER is higher. Some points can have a particular behavior due to singular conditions. CO emissions for D-G are higher than D-E85 in the portion of the map below 4.5 bar IMEP, roughly. Above this engine load, CO emissions for D-E85 are up to $6 \mathrm{~g} / \mathrm{kWh}$ higher than D-G, which supposes near $50 \%$ more emissions considering the net values shown in Figure 9. As RCCI literature demonstrates, in this type of combustion, the $\mathrm{CO}$ to $\mathrm{CO}_{2}$ oxidation process is very sensitive to in-cylinder temperatures. In Figure 13, it is seen that the trend of the maximum bulk gas temperature difference map is consistent with this finding, having almost all the region above 4.5 bar IMEP 100-150 K more temperature with D-G. The low load region has the opposite temperature behavior and therefore higher CO emissions with D-G.
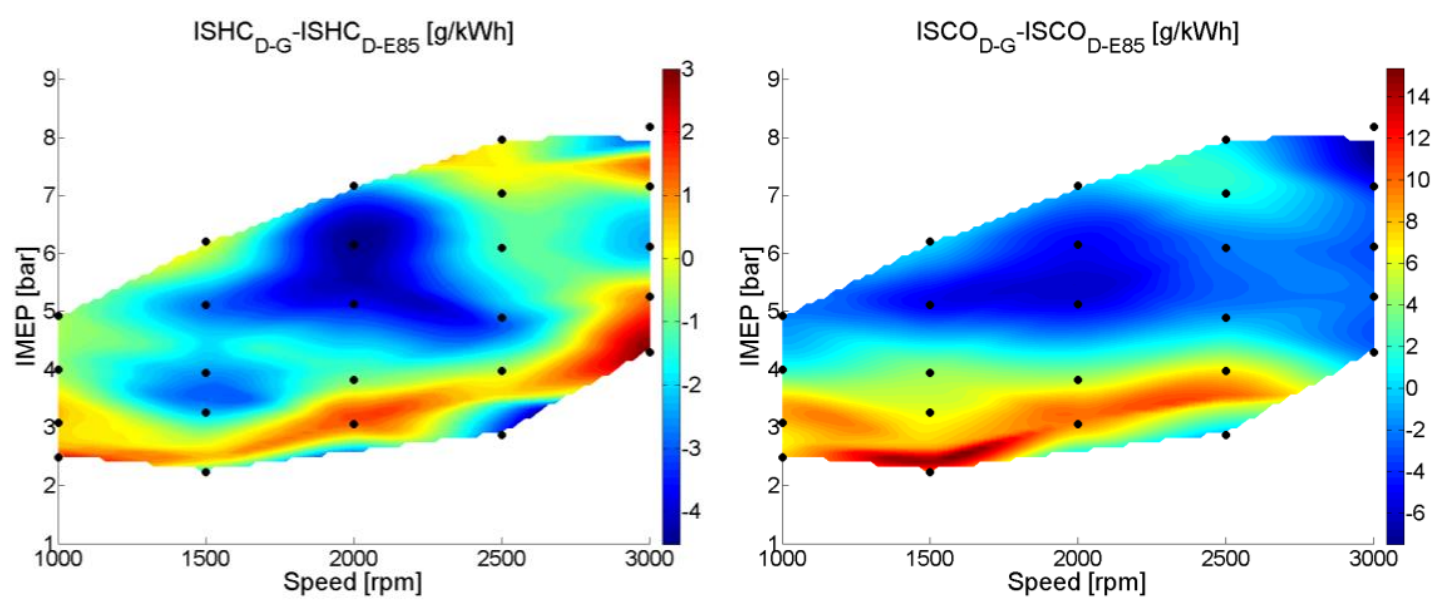

Figure 12. HC and CO difference between diesel-gasoline and diesel-E85 maps.
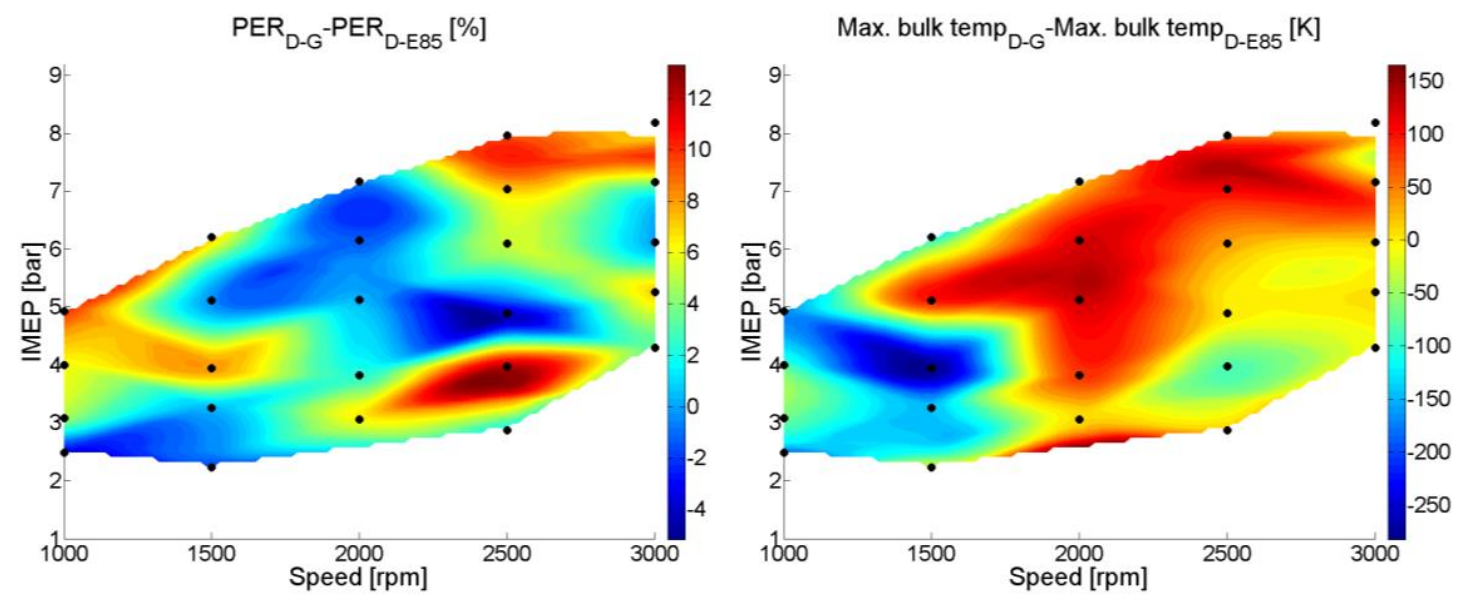

Figure 13. PER and maximum bulk gas temperature difference between diesel-gasoline and diesel-E85 maps.

Figure 14 shows that NOx emissions for D-E85 are higher than D-G in most part of the map. In this sense, only two isolated peninsulas at $2500 \mathrm{rpm}$ show the opposite behavior. Soot emissions are virtually zero for both concepts, showing almost no differences along the map with the exception of two peninsulas in which D-E85 has a greater emission rate. The smoke levels at these points are consequence of particular engine settings combinations. Considering the maps of subsection 3.1, it is expected that the soot rise for D-E85 at these conditions is consequence of using an excessively delayed diesel SOI for the EGR-GF conditions set. 

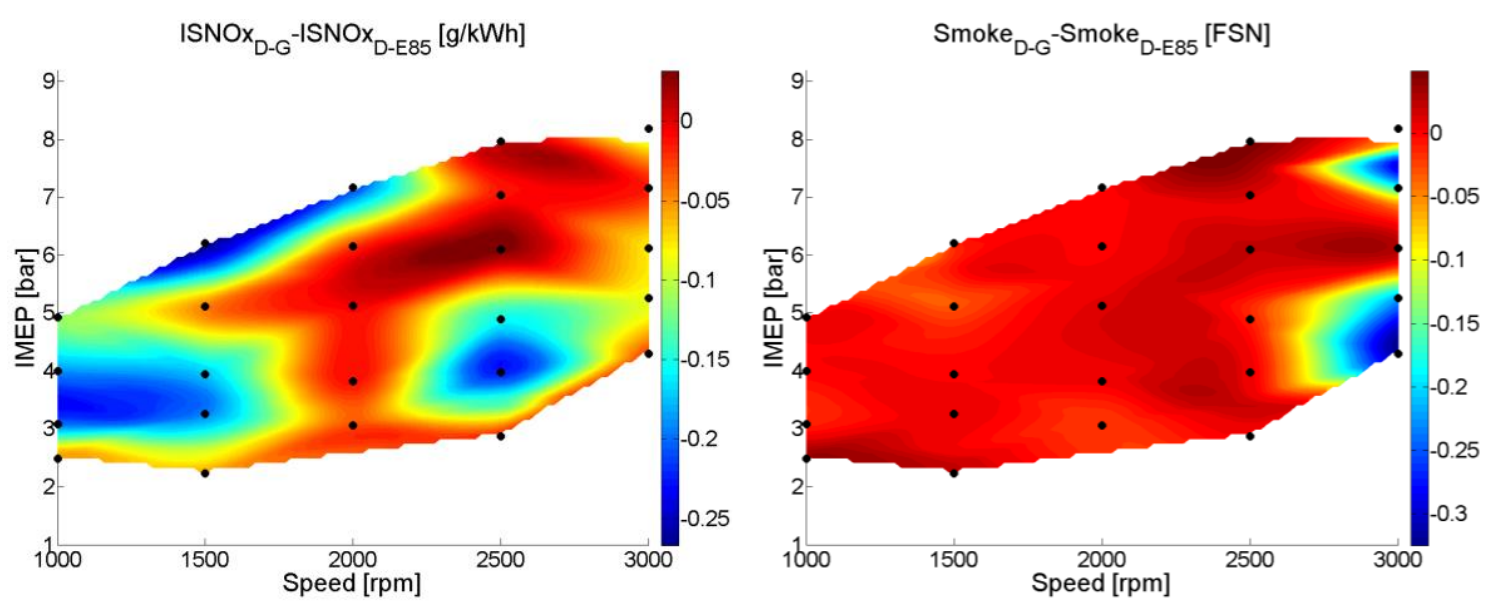

Figure 14. NOx and smoke difference between diesel-gasoline and diesel-E85 maps.

\section{Conclusions}

The present work has evaluated the potential of E85 to be used as low reactivity fuel when applying the $\mathrm{RCCl}$ combustion concept in a high compression ratio light-duty diesel engine. In a first step, steady-state engine maps have been obtained following a defined experimental procedure. Later, the mapping results have been compared to those obtained in a previous work using diesel-gasoline as pair of fuels. To highlight the main differences, a subtraction operation between the maps of both concepts has been done. The main findings of the work can be summarized as follows:

- Under the boundary conditions imposed, the diesel-E85 RCCl concept is limited to the region defined from 2 to 7 bar IMEP at $1000 \mathrm{rpm}$, and from 1.5 to 9 bar IMEP at $3000 \mathrm{rpm}$.

Compared to RCCI diesel-gasoline under the same engine platform and engine mapping procedure:

- The use of E85 allowed to extend the engine map around 2 bar IMEP towards the high load region for all engine speeds when compared to diesel-gasoline.

- The minimum load achieved at the low speed region with E85 remained unchanged versus using gasoline, while at higher engine speeds the low load frontier was reduced down to 1.5 bar IMEP.

- The PER values for RCCI diesel-E85 range from $50-60 \%$ at low load to $75-85 \%$ at high load, similar to those found with diesel-gasoline.

- The sensitivity of CA50 to diesel SOI with E85 is higher than for diesel-gasoline, which improves the control degree over the combustion process.

- Gross indicated efficiency for diesel-gasoline is higher than diesel-E85 at high engine speeds, and vice-versa.

- $\quad \mathrm{HC}$ and CO emissions differences between diesel-E85 and diesel-gasoline has been found to be related to differences in PER and bulk gas temperature, respectively. In general, the emission rate for both pollutants is higher for dieselE85.

- NOx emissions for diesel-E85 are higher than diesel-gasoline in most part of the map, while soot emissions are virtually zero for both concepts. 


\section{Acknowledgments}

The authors gratefully acknowledge General Motors Global Research \& Development for providing the engine used in this investigation. The authors also acknowledge FEDER and Spanish Ministerio de Economía y Competitividad for partially supporting this research through HiReCo project (TRA2014-58870-R).

\section{References}

[1] Garcia A, Monsalve-Serrano J, Heuser B, Jakob M, Kremer F, Pischinger S. Influence of fuel properties on fundamental spray characteristics and soot emissions using different tailor-made fuels from biomass. Energy Conversion and Management, Volume 108, 15 January 2016, Pages 243-254.

[2] Luján JM, Bermúdez V, Dolz V, Monsalve-Serrano J. An assessment of the real-world driving gaseous emissions from a Euro 6 light-duty diesel vehicle using a portable emissions measurement system (PEMS). Atmospheric Environment, Volume 174, Feb 2018, Pages 112-121.

[3] Posada F.; Chambliss S.; Blumberg K. Costs of emission reduction technologies for heavy-duty diesel vehicles. ICCT White paper 2016.

[4] Akagawa H, Miyamoto T, Harada A, Sasaki S, Shimazaki N, Hashizume T, Tsujimura K. "Approaches to Solve Problems of the Premixed Lean Diesel Combustion," SAE Technical Paper 199-01-0183, 1999.

[5] Zheng, M., Asad, U., Reader, G. T., Tan, Y. and Wang, M. (2009), Energy efficiency improvement strategies for a diesel engine in low-temperature combustion. Int. J. Energy Res., 33: 8-28. doi:10.1002/er.1464.

[6] García-Valladolid P, Tunestal P, Monsalve-Serrano J, García A, Hyvönen J. Impact of diesel pilot distribution on the ignition process of a dual fuel medium speed marine engine. Energy Conversion and Management, Volume 149, 1 Oct 2017, Pages 192205.

[7] Yanagihara H, Sato Y, Minuta J. "A simultaneous reduction in NOx and soot in diesel engines under a new combustion system (Uniform Bulky Combustion System e UNIBUS)," In: 17th International Vienna motor symposium; 1996.-14-303, 1996.

[8] Wu HW, Wang RH, Ou DJ, Chen YC, Chen TY. "Reduction of smoke and nitrogen oxides of a partial $\mathrm{HCCl}$ engine using premixed gasoline and ethanol with air," Appl Energy 2011-90-80, 2011.

[9] Koci, C., Ra, Y., Krieger, R., Andrie, M. et al., "Detailed Unburned Hydrocarbon Investigations in a Highly-Dilute Diesel Low Temperature Combustion Regime," SAE Int. J. Engines 2(1):858-879, 2009, doi:10.4271/2009-01-0928.

[10] Harada A.; Shimazaki N., Sasaki S. The effects of mixture formation on premixed lean diesel combustion. SAE Tech Pap 1998, 980533.

[11] Jin Kusaka, Takashi Okamoto, Yasuhiro Daisho, Ryouji Kihara, Takeshi Saito, Combustion and exhaust gas emission characteristics of a diesel engine dual- fueled with natural gas, JSAE Review, Volume 21, Issue 4, October 2000, Pages 489-496, ISSN 0389-4304, http://dx.doi.org/10.1016/S0389-4304(00)00071-0.

[12] Yang B, Yao M, Cheng WK, Li Y, Zheng Z, Li S. Experimental and numerical study on different dual-fuel combustion modes fueled with gasoline and diesel. Appl Energy 2014-33-113, 2014. 
[13] Lewander M, Ekholm K, Johansson B, Tunestal P Milovanovic Nebojsa, KN, Harcombe T, Bergstrand P. "Investigation of the Combustion Characteristics with Focus on Partially Premixed Combustion in a Heavy duty Engine," SAE Int. J. Fuels Lubr. , 2008-06-1063, 2008.

[14] Splitter D, Wissink M, DelVescovo D, Reitz R. RCCI Engine Operation Towards 60\% Thermal Efficiency. SAE Technical Paper 2013-01-0279, 2013, doi:10.4271/2013-010279.

[15] Singh AP.; Agarwal AK. Combustion characteristics of diesel $\mathrm{HCCl}$ engine: an experimental investigation using external mixture formation technique. Appl Energy 2012, 99, 116-25.

[16] Maurya RK.; Agarwal AK. Experimental investigation on the effect of intake air temperature and air-fuel ratio on cycle-to-cycle variations of $\mathrm{HCCl}$ combustion and performance parameters. Appl Energy 2011, 88, 1153-63.

[17] Najafabadi MI, Aziz NA. "Homogeneous charge compression ignition combustion: challenges and proposed solutions," J. Combustion, 2013-783, 2013.

[18] Manente V, Tunestal P, Johansson B et al." Effects of Ethanol and Different Type of Gasoline Fuels on Partially Premixed Combustion from Low to High Load," SAE Technical Paper 2010-01-0871, 2010.

[19] Singh AP, Agarwal AK. "Combustion characteristics of diesel $\mathrm{HCCl}$ engine: an experimental investigation using external mixture formation technique," Appl Energy 2012-25-99:116, 2012.

[20] Xiangyu Zhang, Hu Wang, Zunqing Zheng, Rolf Reitz, Mingfa Yao, Experimental investigations of gasoline partially premixed combustion with an exhaust rebreathing valve strategy at low loads, Applied Thermal Engineering, Volume 103, 25 June 2016, Pages 832-841, ISSN 1359-4311, http://dx.doi.org/10.1016/j.applthermaleng.2016.04.147.

[21] Kalghatgi GT. "Auto-ignition quality of practical fuels and implications for fuel requirements of future SI and $\mathrm{HCCl}$ engines," SAE paper 2005-01-0239, 2005.

[22] Kalghatgi G, Risberg P, Angstrom H. "Advantages of fuels with high resistance to autoignition in late-injection, low-temperature, compression ignition combustion," SAE Trans 2006-34-623, 2006.

[23] Benajes J, Molina S, García A, Monsalve-Serrano J, Durrett R. Performance and engine-out emissions evaluation of the double injection strategy applied to the gasoline partially premixed compression ignition spark assisted combustion concept. Applied Energy, Volume 134, 2014, Pages 90-101.

[24] Benajes J, Molina S, García A, Monsalve-Serrano J, Durrett R. Conceptual model description of the double injection strategy applied to the gasoline partially premixed compression ignition combustion concept with spark assistance. Applied Energy, Volume 129, 2014, Pages 1-9.

[25] Inagaki K, Fuyuto T, Nishikawa K, Nakakita K, Sakata I. “Dual-Fuel PCl Combustion Controlled by In-Cylinder Stratification of Ignitability," SAE Technical Paper 2006-010028, 2006.

[26] Kokjohn SL, Hanson M, Splitter D, Reitz RD. "Experimental Moodeling of DualFuel $\mathrm{HCCl}$ and $\mathrm{PCCl}$ Combustion Using In-Cylinder Fuel Blending," SAE Technical Paper 2009-01-2647, 2009. 
[27] Benajes J, Pastor JV, García A, Monsalve-Serrano J. The potential of RCCl concept to meet EURO VI NOx limitation and ultra-low soot emissions in a heavy-duty engine over the whole engine map. Fuel, Volume 159, November 2015, Pages 952-961.

[28] Benajes J, Molina S, García A, Monsalve-Serrano J. Effects of Direct injection timing and Blending Ratio on RCCl combustion with different Low Reactivity Fuels. Energy Conversion and Management, Volume 99, July 2015, Pages 193-209.

[29] Benajes J, García A, Monsalve-Serrano J, Boronat V. Achieving clean and efficient engine operation up to full load by combining optimized $\mathrm{RCCl}$ and dual-fuel dieselgasoline combustion strategies. Energy Conversion and Management, Volume 136, 15 March 2017, Pages 142-151.

[30] Yang Y, Dec J, Dronniou N, Sjöberg M. Tailoring $\mathrm{HCCl}$ heat-release rates with partial fuel stratification: Comparison of two-stage and single-stage-ignition fuels. Proceedings of the Combustion Institute, Volume 33 (2), pp. 3047-3055, 2011.

[31] Curran S, Gao Z, Wagner R. Reactivity Controlled Compression Ignition Drive Cycle Emissions and Fuel Economy Estimations Using Vehicle Systems Simulations with E30 and ULSD. SAE International Journal of Engines 7(2):2014, doi:10.4271/2014-01-1324.

[32] Benajes J, García A, Monsalve-Serrano J, Balloul I, Pradel G. Evaluating the reactivity controlled compression ignition operating range limits in a highcompression ratio medium-duty diesel engine fueled with biodiesel and ethanol. International Journal of Engine Research, Volume 18 (1-2), Pages 66-80, 2017.

[33] Benajes J, García A, Monsalve-Serrano J, Balloul I, Pradel G. An assessment of the dual-mode reactivity controlled compression ignition/conventional diesel combustion capabilities in a EURO VI medium-duty diesel engine fueled with an intermediate ethanol-gasoline blend and biodiesel. Energy Conversion and Management, Volume 123, July 2016, Pages 381-391.

[34] Benajes J, García A, Monsalve-Serrano J, Boronat V. An investigation on the particulate number and size distributions over the whole engine map from an optimized combustion strategy combining RCCl and dual-fuel diesel-gasoline. Energy Conversion and Management, Volume 140, 15 May 2017, Pages 98-108.

[35] Benajes J, García A, Monsalve-Serrano J, Boronat V. Gaseous emissions and particle size distribution of dual-mode dual-fuel diesel-gasoline concept from low to full load. Applied Thermal Engineering, Volume 120, 25 Jun 2017, Pages 138-149.

[36] García A, Monsalve-Serrano J, Rückert Roso V, Santos Martins M. Evaluating the emissions and performance of two dual-mode RCCl combustion strategies under the World Harmonized Vehicle Cycle (WHVC). Energy Conversion and Management, Volume 149, 1 Oct 2017, Pages 263-274.

[37] Tutak W. Bioethanol E85 as a fuel for dual fuel diesel engine. Energy Conversion and Management, Volume 86, Pages 39-48.

[38] Tutak W, Lukács K, Szwaja S, Bereczky Á. Alcohol-diesel fuel combustion in the compression ignition engine. Fuel, Volume 154, Pages 196-206.

[39] Splitter D, Reitz R, Hanson R. High Efficiency, Low Emissions RCCI Combustion by Use of a Fuel Additive. SAE Int. J. Fuels Lubr. 3(2):742-756, 2010, https://doi.org/10.4271/2010-01-2167.

[40] Ryskamp R, Thompson G, Carder D and Nuszkowski J. The Influence of High Reactivity Fuel Properties on Reactivity Controlled Compression Ignition Combustion. SAE Technical Paper 2017-24-0080, 2017. 
[41] Benajes J, Molina S, García A, Monsalve-Serrano J. Effects of low reactivity fuel characteristics and blending ratio on low load $\mathrm{RCCl}$ (reactivity controlled compression ignition) performance and emissions in a heavy-duty diesel engine. Energy, Volume 90, October 2015, Pages 1261-1271.

[42] Sarjovaara T, Larmi M. Dual fuel diesel combustion with an E85 ethanol/gasoline blend. Fuel, 139 (2015), pp. 704-714.

[43] Tutak W, Jamrozik A, Pyrc M, Sobiepański M. Investigation on combustion process and emissions characteristic in direct injection diesel engine powered by wet ethanol using blend mode. Fuel Processing Technology, Volume 149, August 2016, Pages 86-95.

[44] Li Y, Jia M, Chang Y, Xie M, Reitz R. Towards a comprehensive understanding of the influence of fuel properties on the combustion characteristics of a $\mathrm{RCCl}$ (reactivity controlled compression ignition) engine. Energy, Volume 99, March 2016, Pages 69-82.

[45] Tutak W, Jamrozik A, Pyrc M, Sobiepański M. A comparative study of cocombustion process of diesel-ethanol and biodiesel-ethanol blends in the direct injection diesel engine. Applied Thermal Engineering, Volume 117, 5 May 2017, Pages 155-163.

[46] Benajes J, García A, Monsalve-Serrano J, Villalta D. Exploring the limits of the reactivity controlled compression ignition combustion concept in a light-duty diesel engine and the influence of the direct-injected fuel properties. Energy Conversion and Management, Volume 157, February 2018, Pages 277-287.

[47] Olmeda P, Martin J, Garcia A, Villalta D, Warey A, Domenech V. A Combination of Swirl Ratio and Injection Strategy to Increase Engine Efficiency. SAE International Journal of Engines 10(3):2017, doi:10.4271/2017-01-0722.

[48] Payri F, Olmeda P, Martín J, García A. A complete OD thermodynamic predictive model for direct injection diesel engines. Applied Energy, Volume 88, Issue 12, December 2011, Pages 4632-4641.

[49] Sarjovaara T, Larmi M, Vuorinen V. Effect of charge air temperature on E85 dualfuel diesel combustion. Fuel, Volume 153, Pages 6-12.

[50] Benajes J, García A, Monsalve-Serrano J, Boronat V. Dual-Fuel Combustion for Future Clean and Efficient Compression Ignition Engines. Applied Sciences 7(1):36, 2017.

[51] Benajes J, García A, Pastor JM, Monsalve-Serrano J. Effects of piston bowl geometry on Reactivity Controlled Compression Ignition heat transfer and combustion losses at different engine loads. Energy, Volume 98, March 2016, Pages 64-77.

[52] Desantes JM, Benajes J, García A, Monsalve-Serrano J. The Role of the In-Cylinder Gas Temperature and Oxygen Concentration over Low Load RCCl Combustion Efficiency. Energy, Volume 78, December 2014, Pages 854-868.

\section{Abbreviations}

ASTM: American Society for Testing and Materials

ATDC: After Top Dead Center 
CAD: Crank Angle Degree

CA50: Crank angle at 50\% mass fraction burned

CDC: Conventional Diesel Combustion

$\mathrm{Cl}$ : Compression Ignition

CO: Carbon Monoxide

$\mathrm{CO}_{2}$ : Carbon Dioxide

DOC: Diesel Oxidation Catalyst

DI: Direct Injection

DMDF: Dual-mode Dual-fuel

DPF: Diesel Particulate Filter

EGR: Exhaust Gas Recirculation

EVO: Exhaust Valve Open

FSN: Filter Smoke Number

GF: Gasoline Fraction

GIE: Gross Indicated Efficiency

HC: Hydro Carbons

$\mathrm{HCCl}$ : Homogeneous Charge Compression Ignition

HRF: High Reactivity Fuel

IMEP: Indicated Mean Effective Pressure

IVC: Intake Valve Close

LHV: Lower Heating Value

LRF: Low Reactivity Fuel

LTC: Low Temperature Combustion

MPRR: Maximum Pressure Rise Rate

NOx: Nitrogen Oxides

PER: Premixed Energy Ratio

PFI: Port Fuel Injection

$P_{\max }:$ Maximum Pressure

PPC: Partially Premixed Charge

RCCl: Reactivity Controlled Compression Ignition

RoHR: Rate of Heat Release 
RON: Research Octane Number

SOC: Start of Combustion

SOI: Start of Injection

SCE: Single Cylinder Engine

SCR: Selective Catalytic Reduction 